O'Connell, J.F. and Williams, G. 2005. Passengers' perceptions of low cost airlines and full service carriers: a case study involving Ryanair, Aer Lingus, Air Asia and Malaysia Airlines. Journal of air transport management, 11(4), pages 259-272.

Elsevier, ISSN 0969-6997, DOI 10.1016/j.jairtraman.2005.01.007

\title{
Passengers' perceptions of low cost airlines and full service carriers - A case study involving Ryanair, Aer Lingus, Air Asia and Malaysia Airlines
}

\author{
John F. O’Connell, George Williams*
}

Air Transport Group, College of Aeronautics, Cranfield University, Bedfordshire, MK43 OAL, UK

\begin{abstract}
Direct competition between full service airlines and no-frills carriers is intensifying across the world. American and European full service airlines have lost a significant proportion of their passengers to low cost carriers, the experience now being repeated in the domestic markets of Asia. This paper attempts to provide answers to a number of critical questions: What are the key drivers of each type of airline's business model? Is there a difference in passengers' perceptions between low cost carriers and full service incumbents in a mature European market and in a rapidly developing Asian economy? What are the principle reasons why a passenger chooses a particular airline model? How could a legacy carrier encourage passengers to return and so regain their domestic market share? These questions are addressed using information obtained in passenger surveys that were recently conducted in Europe and Asia.
\end{abstract}

Keywords: full service airline, low cost carrier, Aer Lingus, Ryanair, Malaysia Airlines, Air Asia.

\footnotetext{
* Corresponding Author. Tel.: +44-1234-754239; fax: +44-1234-752207

E-mail addresses: john.f.oconnell@cranfield.ac.uk, george.williams@cranfield.ac.uk
} 


\subsection{Introduction}

The aim of this paper is to compare passengers' selection criteria between a full service airline and a low cost carrier in a mature European market and in a rapidly growing Asian economy. Surveys have been undertaken to ascertain why passengers are choosing one particular airline over another. Passenger surveys involving Ryanair and Air Asia have not previously been conducted and this paper therefore contributes to the literature by examining the differences in passengers' perceptions between the two airline models in contrasting geographical markets.

The paper begins by examining the background of the selected carriers including traffic carried and operating cost performance. It then concentrates primarily on the surveys that were conducted in Europe and Asia, highlighting key findings such as passenger characteristics, journey purpose, booking methods, fares, connecting traffic, carrier choice criteria and types of trips undertaken in the previous twelve months.

\subsection{Background of the airlines surveyed}

Low cost carriers have reshaped the competitive environment within liberalised markets and have made significant impacts in the world's domestic passenger markets, which had previously been largely controlled by full service network carriers. In Europe, 14\% of Available Seat Miles are now provided by low cost airlines, with the two largest players easyJet and Ryanair accounting for nearly 9\%. These carriers have pursued simplicity, efficiency, productivity and high utilization of assets to offer low fares. Table 1 below provides a summary of the main differentiating characteristics between incumbent network carriers and no-frills scheduled airlines.

\section{Table 1}

Prior to 2002, there were no significant low cost scheduled carriers operating in the AsiaPacific rim. Carriers such as JAL Express, Air Do and Skymark in Japan and Citilink in Indonesia existed some years earlier, but did not significantly impact their respective markets. The initial slow development was in part due to the perception that the low cost model adopted in the United States and Europe could not be replicated in Asia, because of the longer aircraft stage lengths, lack of secondary airports and regulatory restrictions preventing access to international markets. The latter being particularly relevant given that the bulk of traffic and revenues are drawn from international markets in Asia.

Thus, the low cost experience is a relatively new phenomenon in the Asia Pacific rim with much of the necessary management experience brought in from outside the region, for example, from Ryanair. Asian low cost carriers accordingly are in the initial growth phase of their development, while many of their American and European counterparts are approaching or have reached maturity. Due to this, little data is available about low cost 
operations in Asia. Table 2 highlights the surge in low cost airlines commencing operations in the Asia Pacific rim within the last two years.

\section{Table 2}

\subsection{Ryanair and Aer Lingus}

Figures 1a and 1b below show the annual passenger traffic carried by Ryanair and Aer Lingus between 1997 and 2003 and their respective falling unit cost levels over this period. The incumbent has managed to reduce its unit cost to a level that it can now challenge its low fare rival. The carrier's business model has been effectively reshaped in order for it to compete out of Irish markets with Ryanair.

\section{Figures 1a \& 1b}

When Ryanair was restructured and re-launched as a low cost carrier in 1991, it carried 0.7 million passengers and Aer Lingus transported 3.7 million. It took only 7 to 8 years for Ryanair to catch up. Fares charged by Aer Lingus on the Dublin-London and Cork London routes were cut by 70\% when Ryanair entered the market (Barrett, 1999).

During the late 1990s and early 2000s, Ryanair achieved a compound annual traffic growth rate of $30.5 \%$. The company has set itself the target of becoming the largest airline in Europe with over 40 million passengers a year (Ryanair, 2002). This ambitious plan is evidenced by the airline taking delivery of its $51^{\text {st }}$ Boeing 737-800 in March 2004. In late 2003 the carrier ordered 125 Boeing 737-800s and placed options on a further 125 (ATI, 2003). It increased its capacity by 44\% in 2003 alone and has tripled its seat capacity overall since 2000 .

A significant proportion of its earnings are derived from ancillary revenues. In 2003, the carrier made $€ 28$ million from commissions on car rentals, €23 million from in-flight sales, $€ 12$ million from Internet sales and $€ 35$ million from non-flight sales. It also gave away 20\% of its flights for nothing in 2003 and aims for 50\% free seats by 2009 .

Aer Lingus, the Irish flag carrier, which is 95\% state-owned and part of the Oneworld alliance, now carries over 6 million passengers annually using 7 long-haul Airbus aircraft and 24 short-range types. The carrier's 120 weekly transatlantic flights account for $40 \%$ of its revenue. Traffic feed via code sharing to British Airways at London Heathrow is key to its UK-Ireland profitability. 88\% of Aer Lingus' cargo business is accounted for by its transatlantic and German markets, however airfreight overall is important to Ireland as nearly one-quarter of the country's exports and imports by value are transported by air.

Aer Lingus's structural reformation into a low fares airline caused Ryanair's profits on the city pair to fall by $20 \%$ in 2003. In 2001, Aer Lingus had accumulated a net loss of $€ 149$ million and was losing $€ 2.5$ million a day, with passenger numbers having fallen by $4.6 \%$ over the previous year. The new management instigated a survival plan targeting an 
annual cost reduction of $16 \%$, representing $€ 90$ million. The carrier turned in a net profit of €69 million in 2003, producing an operating margin of 9.3\%. Between 2001 and 2003, the transformed carrier increased its passenger traffic by $7 \%$ and its load factor by $11 \%$, while reducing seat capacity by $6 \%$. Over the same period, Aer Lingus managed to reduce its operating costs significantly as a newly focused management team trimmed $31 \%$ off fuel costs, $28 \%$ from airport charges, $51 \%$ off aircraft rentals, $12 \%$ from maintenance, $53 \%$ off distribution, $21 \%$ from staff cuts, $36 \%$ off overheads, $21 \%$ from depreciation and $49 \%$ off other miscellaneous direct operating costs, which netted the carrier an overall saving of €340 million.

Tables 3 and 4 provide details of the passenger traffic carried by Aer Lingus and Ryanair between each main Irish airport and the five London airports between 1997 and 2002. The growth in traffic carried by Ryanair between 1997 and 2002 is very high, with Dublin - Stansted increasing by 36\% and Cork-Stansted by 58\%, while Shannon-Stansted grew by 300,000 passengers in just over three years. Aer Lingus has also witnessed a growth in its traffic, with passenger numbers on the Dublin-Heathrow route increasing by 29\% and on Cork-Heathrow by 30\% between 1997 and 2002. The traffic carried by Aer Lingus on the Shannon-Heathrow route however remained flat over this period.

\section{Table 3}

\section{Table 4}

By the end of 2002, low cost carriers accounted for one-third of the total intra-European market involving the UK and Ireland. Between Ireland and the UK, low cost carriers accounted for $47.2 \%$ of the traffic (Aviation Strategy, January 2003). By 2004, Ryanair has carried over 45 million passengers to/from Ireland since operations commenced in 1985 (Ryanair, 2004).

According to forecasts from Tourism Ireland, approximately 7.7 million tourists are expected to visit in 2005 and the tourism minister is expected to invest over $€ 110$ million in support of tourism of which almost $€ 70$ million will be spent in support of marketing and promotion. Travellers from Britain, France, Germany and the US accounted for $83 \%$ of the total number of visitors to Ireland in 2002.

\subsection{Air Asia and Malaysia Airlines}

The history of Malaysia's Air Asia is similar to that of Ryanair, as both carriers have transformed themselves from loss making regional operators to profitable low cost airlines. Perhaps this is not surprising, given that Air Asia is managed by Conor McCarthy, an ex-Ryanair director. Besides attracting passengers from buses and ferries, both carriers have experienced a large proportion of first time flyers, largely attracted by the low fares on offer.

Air Asia currently has a 30\% share of the domestic Malaysian market. Since the airline's inception in December 2001, the market has grown from 9 million passengers annually to 13 million. Bankers are valuing the carrier between $\$ 750$ million to $\$ 1.2$ billion (Ionides, 
2004). Currently, the airline has 14 Boeing 737-300s in its fleet and by the end of 2004 it will have acquired up to 30 aircraft, representing a 114\% compound growth in capacity. In mid June 2004, it issued a tender to manufacturers that it was interested in acquiring up to 80 new aircraft comprising 40 firm orders and 40 options (ATI, June 2004).

Figures 2a and 2b show passenger enplanements and unit costs for Malaysia Airlines and Air Asia between 1998 and 2004. The unit cost differential is very significant and is due to Malaysia Airlines excessive labour force, its poor productivity, low aircraft utilisation, unprofitable domestic routes and the limitations of intra-Asian bilaterals.

\section{Figures 2a \& 2b}

With the world's lowest unit cost of US\$0.023/ASK and a passenger break-even load factor of 52\%, Air Asia is showing all the signs of being a Ryanair clone. It has hedged $100 \%$ of its fuel requirements for the next three years, achieves an aircraft turnaround time of 25 minutes, has a crew productivity level that is triple that of Malaysia Airlines and achieves an average aircraft utilisation rate of 13 hours a day. In comparison, Malaysia Airlines has hedged only $20 \%$ of its fuel requirements, achieves one-hour turnaround times and has an aircraft utilisation rate in the domestic market of just over 8 hours a day. Air Asia has captured the growth in the domestic market of 4-5\% in 2003 and consequently left Malaysia Airlines with stagnant traffic.

Equipped with a strong low cost formula, Air Asia is beginning to move into new intraAsian markets, such as Thailand, by developing a franchise, under the brand name 'Thai Air Asia'. It is taking a 49\% shareholding in the franchise, with the remaining shares being taken up by the Thai Prime Minister's Thaksin Shinawatra's Shin Corporation, which will enable the carrier to operate by acquiring international landing rights in what would otherwise be a tightly regulated environment. The partnership with the Thai government is having its benefits, as Sreenivasan (2003) has revealed. The current Thai transport minister Suriya Jungrungreangkit will remove the current minimum airfare regulations in order to open up the Thai market. The minimum airfare ruling was established to prevent the undercutting of fares in the local market, with the probable intention of safeguarding Thai airlines.

Air Asia has also pushed forward with its expansion program into Indonesia, where it is operating out of three cities: Jakarta, Surabaya and Bandung. It is offering tickets priced between $40 \%$ and $50 \%$ lower than the other domestic carriers. This growth outside the domestic Malaysian market follows a similar strategy of Ryanair and easyJet in Europe, which have expanded by creating hubs in different neighbouring countries. This was achieved in the EU as a result of full deregulation of the sector, however. The tightly regulated international intra-Asian market is a major obstacle to the full-scale development of low cost carriers in the region.

Malaysia Airlines, the country's flag carrier, is over $90 \%$ owned by the government. It carries over 16 million passengers annually and has extensive code sharing agreements with 24 international airlines. The carrier's fleet consists of 100 aircraft of which $54 \%$ are used in the domestic and intra-Asian markets. A further 10 aircraft are on order, including 
6 A380s. It has an extensive overhaul and maintenance facility that specialises in engine and avionics repair. The currency crisis of 1997, followed by three successive years of poor revenues and a debt of \$2.6 billion forced the Malaysian Government to intervene and rescue the airline. It transferred ownership of 73 aircraft, leases on another 17 and liabilities of $\$ 1.8$ billion to the Malaysian Finance Ministry (Penerbangan Malaysia Berhad PMB). As a result, Malaysia Airlines today with nearly 22,000 employees operates on behalf of PMB. In 2002, the airline achieved a net group profit of $\$ 89$ million. Since then, the carrier has posted its best profit since 1985 of $\$ 121.4$ million. However, it has achieved an average operating margin of only $0.3 \%$ in recent years.

\subsection{Methodology}

Using a similar methodology to that adopted by Mason (2001) and Turner (2003), data was collected in each of the two regions from two large groups of passengers, one flying with a low cost carrier and the other an incumbent. Both groups were travelling to the same city destination, but not necessarily to the same airport. There has been no previous research on passengers' perceptions of low cost carriers in Asia.

The airlines surveyed were Aer Lingus and Ryanair operating in the mature European market, and Malaysia Airlines and Air Asia operating in the recently liberalised Malaysian domestic market. The passengers were surveyed in the relaxed open landside area of the airport. The airports where permission was granted to undertake the surveys were Cork, Kerry ${ }^{1}$ and Shannon in Ireland, and Kuala Lumpur International in Malaysia. Large teams of personnel were involved in capturing the data, as pilot studies concluded that the second page of the survey was often omitted and it was important that all questions were understood and fully answered. The personnel also assisted with language barriers and in answering any issues raised regarding the open-ended questions, in which each respondent could give a personal response in his or her own words. A total of 281 responses were collected at the Irish airports, 52\% of which comprised Ryanair passengers, and 247 responses at Kuala Lumpur International airport, 48\% of which were from Air Asia passengers. Each survey was conducted over a period of two days.

\subsection{Survey Findings}

As expected, the low-cost carriers attracted a high number of younger people, with $24 \%$ of the Ryanair passengers surveyed and 47\% of Air Asia's being in the under 24 years age group. $87 \%$ of this age group were travelling for non-business purposes that included visiting friends/family and trips to/from places of education. Parents mostly paid for these trips. For the 25-58 age group, which represented $84 \%$ of those surveyed, passenger choice changed considerably in favour of the incumbent carriers.

\footnotetext{
${ }^{1}$ Only Ryanair flights depart from Kerry airport.
} 
The age segregation between the carrier types is very clear, with the older passengers tending to prefer the incumbent carriers, possibly because these offer additional airline products not offered by the low cost carriers.

Group travel is particularly significant to airline revenues. Business travellers usually tend to travel singularly but leisure travellers often journey in small groups. Low cost airlines carry more passengers who travel as part of a group than do the incumbent airlines, with almost $45 \%$ of Ryanair passengers travelling in pairs and $41 \%$ of Air Asia's passengers travelling as part of a group of people comprising 3 or more.

It is only in recent years that the incumbent carriers have sold discounted one-way tickets. This has been in response to the provision of such fares accessible via the Internet by the low cost carriers. Both low cost carriers surveyed had over $70 \%$ of their passengers purchasing return tickets (72\% in the case of Air Asia and $76 \%$ in the case of Ryanair). Aer Lingus's passengers also had a significantly high percentage, with $80 \%$ booking a return ticket. By contrast, over 18\% of Malaysia Airlines' passengers were travelling on one-way tickets.

The mode of surface access and the distance travelled to the departing airport was also ascertained. The significance of having a frequent high-speed, non-stop train service from the city centre of Kuala Lumpur to the airport was apparent, with one third of the passengers surveyed making use of this. In contrast, there is no such service linking any Irish airport, and on average $76 \%$ of passengers accessed their flights by personal car, which provides a significant income to the airport authorities in parking fees.

Passengers were also asked how far they had travelled to the airport. In Malaysia, those who were using the national flag carrier travelled an average distance of 50 miles to reach the airport, while Air Asia passengers travelled an average of 77 miles. The distance from Kuala Lumpur to the international airport is approximately 40 miles. In Europe, the survey highlighted the fact that Ryanair passengers travelled 44\% further than the incumbent carrier's passengers in order to reach the airport. Lawton (2002) and Doganis (2001) have both referred to the fact that European passengers flying on a low cost carrier are travelling further to reach their departure airport. The positioning of secondary airports large distances from the major cities does not seem to pose a significant barrier to the use of low fare carriers.

Finally, questions were asked about the type of accommodation used. There was a noticeable difference in the type of accommodation used by low cost airline users in Europe and those in Asia. 31\% of Ryanair's passengers stayed in hotels, while almost $49 \%$ of Air Asia's passengers stayed in places such as inns, guesthouses, bed and breakfast establishments, or hostels. The European travel trade has often suggested that passengers who travel on a low cost carrier tend to use the savings that were derived from the lower fares in staying at more luxurious accommodation, such as a hotel. The incumbent carriers' passengers tended to opt for hotels, which generally reflects their requirement for additional full service attributes, with an average of $39 \%$ of them staying in this type of accommodation. 


\subsection{Journey Purpose}

Table 5 shows journey purpose and as expected, the two incumbent airlines carried a significant proportion of business traffic, with meetings being the primary reason for the trip. However, almost $29 \%$ of the Ryanair passengers surveyed were also travelling on business, which was only $8.5 \%$ less than the equivalent figure for Aer Lingus. Of significance here is the fact that Ryanair is operating to a secondary airport, which adds time and inconvenience for business travellers in getting into central London. Some $40 \%$ of the passengers travelling for business purposes with Ryanair were going to events such as conferences and training courses. These journeys would generally be considered as being less urgent business trips. The low p-value means that the difference between the carriers is unlikely to be due to chance.

\section{Table 5}

Approximately 8\% of Air Asia passengers, all of whom were male, were travelling for business purposes. The low p-values for the Asian carriers cited above reflects the fact that passengers are more likely to travel on Malaysia Airlines for meetings and conferences and are more likely to travel on Air Asia for sporting events and that these differences are statistically significant. In more mature European markets however, this trend is somewhat reversed.

Table 6 provides details of the sizes of companies that the business passengers surveyed work for. It is perhaps not so surprising that such a high proportion of self-employed people choose the low cost carriers. A cross tabulation of self employed passengers and primary reason for choice of a low cost carrier revealed that $91 \%$ of these travellers chose the carrier primarily due to the fare and were not attracted by the extended full service products offered by the incumbent airlines. Business passengers travelling on incumbent airlines tend to come from larger companies that employ over 100 people. These companies would generally have larger travel budgets and would adopt corporate travel policies. Mason (2001) states that $73 \%$ of business passengers he surveyed at Heathrow had a company corporate travel policy, as opposed to 55\% of the travellers using a low cost carrier at Luton airport. Over one third of Aer Lingus and Malaysia Airlines business passengers work for companies that employ over 1000 people, indicating corporate preference for the additional airline products that the full service carriers provide.

\section{Table 6}

The low cost carriers attracted proportionately more leisure traffic, with. Ryanair and Air Asia having respectively $10 \%$ and $22 \%$ higher proportions of their traffic comprising leisure users than their incumbent counterparts. It was also apparent that the biggest leisure market segment comes from those passengers who regularly visit friends and family. 
Paci (1994) showed that the Asian leisure market, and in particular, the VFR segment was steadily growing and that culturally, time spent with family and friends is a very important leisure activity. Air Asia's VFR traffic represents almost a quarter of its total market, while that of Malaysia Airlines fewer than 17\%. This segment represented the largest number of passengers carried on both surveyed airlines. Student travel accounted for the second largest non-business market. Cross-referencing indicated that most of this travel was paid for by parents, although the choice of airline was largely selected by the students. Most of these students have migrated from travelling on trains and buses to Air Asia. Overall, a large proportion of Air Asia's passengers are first time flyers (Aviation Strategy, May 2003). The brand perception of lower fares, large network, high advertising awareness campaigns and 24 hour booking via the Internet is certainly pushing the Malaysian low cost carrier's non-business market.

The rivalry for domestic market share in Malaysia is just beginning to surface. Air Asia has taken away the annual domestic passenger market growth of $4-5 \%$ from Malaysia Airlines as domestic leisure traffic was stagnant in 2003 for the incumbent. This may be in part due to the fact that Malaysia Airlines does not advertise its domestic route network in the local media, in contrast to Air Asia, which has an aggressive media presence, somewhat mirroring that of Ryanair.

Between 1993 and 1999, which covered the establishment and growth phase of Ryanair, annual VFR traffic from Ireland to the UK grew from around 500,000 to 835,000. The effect is even more revealing when considering VFR traffic from the UK to Ireland, which grew from 950,000 to 1.8 million per year over the same period (Mintel, 2000). This growth was primarily due to the large second and third generation Irish-British population living in the UK. VFR traffic constituted the largest segment of non-business passengers surveyed, with respectively $20.5 \%$ of Aer Lingus and $27.7 \%$ of Ryanair passengers travelling for this purpose.

The second biggest non-business segment consisted of passengers travelling for holiday and short break purposes. Both the low cost carriers sampled carry more of this type of traffic than the incumbents. In Europe, low cost scheduled carriers have encroached on the charter market. Williams (2001) argues that package tour charter carriers are vulnerable to low cost airlines on sectors of up to 2.5 hours, given that travellers can now integrate their own flights and accommodation into personalised package holidays via low cost carrier websites. However this is not the case in Malaysia, where there is an absence of such charter airlines.

Short holiday breaks have become very significant representing an important market in the leisure sector. The two low cost carriers attracted slightly more short break travellers than the incumbents, with this sector accounting for an average of $12.5 \%$ of their traffic. Mintel (2002) estimates that UK nationals took 5.6 million short breaks in 2002, which represents around 15\% of all UK holidays abroad. By 2005 this figure is forecast to increase to 7.2 million, accounting for around one fifth of international holidays. 
The low cost airlines are extending their brands to capture this short break market. Air Asia is marketing inclusive packages on its website under 'Go Holiday', offering a wide range of mini-breaks consisting of 2-3 nights. Ryanair also offers short break packages and advertises leisure activities on its website. These packages form an important part of additional ancillary revenue with the low cost airlines integrating package holidays into their core business model. These short break packages are generally absent from both the Aer Lingus and Malaysia Airlines websites.

Attending sports events is the journey purpose for around one tenth of travellers. It was apparent that over $80 \%$ of groups that consisted of 4 or more passengers were travelling to sporting fixtures. Sporting activities are usually considered unimportant by tour operators and are left to the competencies and/or skills of local suppliers. It would appear therefore that there is ample opportunity for low cost airlines to capitalise on this market.

\subsection{Booking Methods}

Table 7 below shows the distribution channels used by the passengers surveyed. The carriers are significantly associated with method of booking, with Ryanair passengers more likely to use the website (78\%) than Aer Lingus passengers (58\%). Many Aer Lingus passengers used a travel agent (16\%), whereas this type of booking channel was not available to Ryanair passengers. There was no significant difference in the use of other booking methods. The contrast is even more apparent between Malaysia Airlines and Air Asia, with the latter's passengers predominantly using the Internet to book their tickets and generally avoiding travel agents, while Malaysia Airlines passengers do the opposite. Malaysia Airlines in particular stands out, as there were no passengers that booked online due to the incumbent only introducing its online booking engine in late January 2004, when passengers became able to purchase domestic tickets to a select number of destinations. This would seem to confirm the findings of Gillan and Lall (2002), as the majority of tickets purchased were via travel agents or call centres. In 2001, roughly $10 \%$ of the Malaysian population had personal computers, but this had increased to $18 \%$ by 2003 , this technology enabling the development of low cost travel (Thomas, 2003). Low cost airlines are forcing change through the competitive advantage of online distribution and it is predicted that $25-30 \%$ of all Asian airline ticket sales will be online by 2005 (Ionides, 2001).

\section{Table 7}

There are only a small number of incumbents that have fully functional e-commerce websites in Asia, including Singapore Airlines and Cathay Pacific. Low cost airlines are formulated so that a large proportion of their sales are conducted via direct channels, such as host websites. Air Asia launched its online sales facility via www.airasia.com in its fifth month of operation and was the first airline in Asia to introduce Internet booking with online payments and ticket less travel. By May 2003, 45\% of its bookings were made through the Internet (Thomas, 2003). The carrier is extremely innovative, being the first airline worldwide to offer SMS booking, and is processing 2,000-3,000 messages per month. Additional channels include 10 sales offices and call centres each equipped with 
over 180 lines that take 6,000 calls a day. The carrier has also been innovative in providing alternative distribution channels, such as enabling passengers to book tickets at post offices.

Direct bookings were made by over 64\% of Air Asia's passengers surveyed. This rises to $73.7 \%$ if the additional channels of office booked and family/friends are included. The call centre channel accounted for over $13 \%$ of bookings. A relatively large number of tickets $(10 \%)$ were purchased on the day of departure, which normally represents the most expensive time to purchase a ticket.

There is a very noticeable discrepancy between the booking profiles of Malaysia Airlines passengers and those of Air Asia. This reflects the incumbent's inability to implement change (technology) and keep pace with its innovative rival. Even in countries where use of the Internet is not widespread, evidence shows that passengers will seek out all the available booking channels in order to access lower fares.

93\% of Ryanair passengers surveyed booked online (this includes the combination of a number of channels, such as website, office booked and family/friends). Ryanair is now the fifth most searched website worldwide, which demonstrates the strength of the low cost carrier brand. ${ }^{2}$ By contrast, $16.2 \%$ of Aer Lingus passengers used travel agents to book their tickets. Commissions by the carrier to the travel trade in the UK and Ireland have been cut to 1\%; however in continental Europe commissions are still between 4\% and $7 \%$. In November 2001, Aer Lingus sold $1 \%$ of its tickets via the Internet, but by late 2003 its Internet bookings had grown to 50\%, with the carrier handling $10-12 \%$ of sales through its call centre.

$58.1 \%$ of Aer Lingus passengers surveyed booked online. The airline's aggressive marketing campaign in promoting a strong brand is having an effect on the way tickets are now booked. It recently removed the shamrock logo from a number of its aircraft and replaced it with AerLingus.com, demonstrating its willingness to lose its trademark link with tradition and heritage in favour of an innovative and technological logo in order to gain competitive advantage. One of the principle reasons for the carrier's financial reformation and its challenge to Ryanair has been the shift in its distribution channels. Aer Lingus benchmarked its passenger processing costs against those of Ryanair and declared that there was a $€ 20$ difference per passenger between the two carriers, the Internet providing the solution to this cost disadvantage (O’Toole and Pilling, 2003).

\subsection{Fares}

Lawton (2002) pointed out that the average fares of no frills carriers were some 40-60\% lower than their full service competitors. Ryanair's one-way fares averaged 50 Euros in 2002, with the airline having become renowned for stimulating markets through its low fare offerings, which has given rise to the term 'Ryanair effect'.

\footnotetext{
${ }^{2}$ The 2003 Year End Google Zeitgeist survey (based on 55 billion searches over the past year), which tracks the most popular sites, ranks Ryanair.com as the fifth most searched for brand across the worldwide web. Ryanair news, December 22, 2002 at www.ryanair.com
} 
Part of Ryanair's strategy for market stimulation is the issuing of free tickets. For example, in the first six months of 2003, the carrier issued 100,000 free seats to celebrate the opening of its new base at Bergamo in January 2003; 66,000 free seats in May 2003 when its competitor easyJet announced half yearly losses of $€ 66$ million; 70,000 on June $12^{\text {th }}$ to celebrate the fact that it had carried 70,000 more passengers in May than its low fare competitor; and 27,000 on June $16^{\text {th }}$ for having a better level of punctuality for the $27^{\text {th }}$ consecutive week than easyJet. More recently, on April $20^{\text {th }} 2004$, Ryanair celebrated its 80 millionth passenger with 800,000 free seats and by August $19^{\text {th }}$ it reached 90 million and consequently gave away 900,000 seats at 90 pence. In five years' time the carrier plans to give away $50 \%$ of its flights for free. Passengers' perception is therefore to expect low fares from this no frills carrier.

Only passengers on flights going only to the London airports from Ireland were surveyed. The average one-way fare paid by Ryanair passengers was $€ 65$ and the average return fare was $€ 159$. Taxes constituted $€ 19.5$ for Ireland-UK trips, with an additional $€ 21.70$ for the return journey. If these taxes were deducted, then the fares would equate to approximately $€ 45$ one-way and approximately $€ 117$ for return journeys. The Aer Lingus average one-way fare paid by those surveyed was $€ 82$ and the average return fare was $€ 183$. The taxes in this case were higher as the carrier served different airports in the London area. The average one-way tax was approximately €20, and the tax on the return journey was an additional $€ 28$. Again, if these taxes were subtracted then the fares would equate to approximately €62 one-way and $€ 135$ for return journeys.

Table 8 shows the fare differences between the two Malaysian carriers surveyed on a number of routes. Shortly after the government assumed 6.9 billion Ringgits of Malaysia Airlines' debt, the carrier cut fares by $50 \%$ on 14,000 seats a week to compete more effectively with Air Asia in the domestic market. The information shown in Table 8 takes account of these discounted fares.

\section{Table 8}

The low unit cost of Air Asia at US\$0.023 cents per ASK $^{3}$ enables the carrier to offer such low fares. As Malaysia Airlines loses money on its domestic operation, matching the low fares of Air Asia could be harmful to its financial viability, however it needs its domestic network to feed into the Kuala Lumpur hub.

A further question related to how important the fare was in actually choosing a carrier. The results are shown in Figure 3. As expected, fare constituted the principle reason for choosing a low cost carrier. Almost 65\% of Aer Lingus passengers stated that fare had been the sole influencing factor in their choice of airline, while only $31.5 \%$ of Malaysia Airlines passengers did so. It is evident that a significant number of passengers travelling on incumbent carriers are also influenced by factors other than the fare paid.

\footnotetext{
${ }^{3}$ Air Asia has the lowest operating costs in the airline industry.
} 


\section{Figure 3}

An attempt was made to assess the cross-price elasticity of demand between incumbents and low cost carriers. Figure 4 provides an indication of what proportion of a low cost carrier's passengers would switch over to an incumbent if the full service provider reduced its fares respectively by $10 \%, 20 \%$ and $30 \%$. The results show that if Aer Lingus and Malaysia Airlines were to reduce their fares by $10 \%$, then $6.1 \%$ on average of Ryanair's and Air Asia's passengers would switch over to them. A further reduction to $20 \%$ would persuade $19.6 \%$ of Ryanair's passengers and $14.4 \%$ of Air Asia's passengers to switch over to the respective incumbent carrier.

\section{Figure 4}

A significant aim of the survey was to find the fare levels at which a large number of passengers travelling on a low cost carrier would be willing to switch over to an incumbent airline. If the incumbent airlines reduced their fares by $30 \%$, then $45.9 \%$ of Ryanair's passengers and 39.4\% of Air Asia's passengers would be prepared to switch. There are a significant proportion of passengers however who would not transfer to any other carrier. The data shows that $40.6 \%$ of Air Asia's passengers and $28 \%$ of Ryanair's passengers would remain loyal. This is due to a combination of factors, such as brand development, fares, flight schedule, simplified website, package holidays, etc.

Although low cost airlines are relatively new to Asia, they have already developed very strong low fare brands through strong advertising and clever use of the media. The wide perception of people in Malaysia, when acknowledging Air Asia, is that it represents low fares. Gilbert et al. (2001) argue that branding is becoming increasingly important as a means of product and service differentiation, and that the low cost airlines are building brand recognition to compete in such a competitive environment.

Figure 5 provides an indication of what proportion of an incumbent carrier's passengers would switch over to low cost airlines if it raised its fares by respectively $10 \%, 20 \%$ and $30 \%$. This information provides an indication of the amount of fare flexibility that incumbent airlines have and identifies the point at which passengers would begin to shift their custom to low cost carriers. Given incumbents offer the benefit of full service, including interlining, serving primary airports, business class, frequent flyer mileage, etc., some passengers are clearly willing to pay more for these features.

\section{Figure 5}

The survey data shows that fare increases of $10 \%$ and $20 \%$ would persuade approximately $5 \%$ and $14.8 \%$ respectively of the incumbents' passengers to switch to low cost carriers, with the differences between the two carriers not being significant. ${ }^{4}$ If the incumbents however, raised their fares by $30 \%$, then $42.8 \%$ of Aer Lingus's passengers and $48.7 \%$ of Malaysia Airlines passengers would switch. An interesting observation

\footnotetext{
${ }^{4}$ Statistical test of means, $10 \%$ significance level.
} 
derived is that an average of $34.3 \%$ of the incumbents' passengers would remain loyal, possibly due to the wide range of products/facilities offered. ${ }^{5}$

It is clear that low cost carriers offer a strong substitute to the full service airline product. Not surprisingly, this has important implications for marketing and advertising branding, customer loyalty and satisfaction should be carefully considered by every airline. Interestingly, the results of the survey show that cross-price elasticity is not constant - in Figure 4, for example, a small fare reduction $(10 \%)$ by the incumbent triggers a less than proportional switch, while a high one $(30 \%)$ leads to a dramatic change. This defies the usual assumption made in various econometric models of constant cross-price elasticity and shows the importance of absolute fare levels in determining customer choice.

Finally, to complete the discussion, income effects should be considered. Although the survey has not been designed to quantify explicitly any income effect, it is evident that consumer income does play an important role, as less wealthy consumers are more priceconscious and hence more susceptible to a switch between airlines as a result of changes in fares. Having said this, dynamic effects are highly important; air travel does not have the glamour of the past any more and the low cost carriers have managed to develop brands of their own. Therefore, when airport location and total travelling time are similar, low cost carriers may also become the preferred choice of more wealthy customers.

\subsection{Airline Connections}

Figure 6 shows the percentage of connecting traffic for both groups of carriers. A big feature of a full service carrier is the ability to interline traffic at its hub airport. As expected, there is a strong interline requirement for both flag carriers that operate hub and spoke networks. $41.2 \%$ of Aer Lingus passengers surveyed were interlining, as compared to $36.7 \%$ of those of Malaysia Airlines. This reflects an incumbent's ability to leverage 'network benefits' and thus attract a high proportion of passengers who wish to connect seamlessly.

\section{Figure 6}

Low cost airlines operate mostly on a point-to-point basis only. These carriers emphasise that they will not be responsible if passengers fail to make their connections, even if the onward journey is with the same carrier. The risk of failing to make a connection involves the traveller purchasing another ticket. Data from the surveys indicate that passengers are willing to accept that risk. $17.2 \%$ of Ryanair's passengers questioned were transferring to other carriers at London Stansted. Ryanair's creation of traffic bases across Europe has provided the opportunity for passengers to interline using a point-topoint network. Air Asia's transfer traffic was only 5.8\%, which is not surprising as it was only formed in December 2001.

\footnotetext{
${ }^{5}$ Statistical test of means, $5 \%$ significance level.
} 
Figure 7 identifies the principle airlines to which the interlining passengers surveyed were transferring. It is apparent that the incumbent carriers have a significant proportion of their traffic transferring to alliance or code-sharing partners. Aer Lingus had 55.3\% of its connecting passengers questioned transferring to the Oneworld alliance, of which the majority were transferring to British Airways. By contrast, 72\% of Ryanair's passengers surveyed who were making connections continued their journeys from Stansted on other Ryanair flights, while around 20\% connected with easyJet services. Ryanair operates close to $30 \%$ of the daily departures at London Stansted and $12.5 \%$ at Dublin, thus providing numerous permutations of connections and ample opportunity for passengers to transfer to other destinations.

\section{Figure 7}

Malaysia Airlines is not part of an alliance, but $68.5 \%$ of its connecting passengers surveyed were transferring to other code-share flights. Only 6.6\% of Malaysia Airlines passengers questioned connected with Air Asia at Kuala Lumpur. Very few of Air Asia passengers surveyed were transferring: four were connecting to a Malaysia Airlines long haul service, while the remaining three were transferring to Air Asia flights. As the market begins to mature and Air Asia develops additional hubs, there will be a greater opportunity for passengers to transfer to other flights. The perception is evident in the Asian market that passengers can use a combination of carrier types to reach their destinations, and that interlining via a low cost carrier network is certainly a workable option.

\subsection{Principal Reasons for Carrier Selection}

43.8\% of the two incumbents' passengers questioned stated that they had looked at other carriers' offerings prior to booking their flights. ${ }^{6}$ By contrast, $65.2 \%$ of the low cost carriers' passengers surveyed stated that they had not considered other carriers' services prior to booking their flights. ${ }^{7}$

An important element of this research was to establish the principle reason why each passenger had selected a particular airline. A study undertaken by Proussaloglou and Koppleman (1995) on the demand for air carrier services concluded that carrier selection was based on a combination of factors that included the airline's market presence, schedule convenience, low fares, on time performance, reliability and the availability of frequent flier programs. Figure 8 provides confirmation of their results, with the evidence from this survey that passengers choose a full service carrier for a variety of reasons, including: service reliability, service quality, flight schedules, fares, connections, frequent flyer programs, comfort, safety and company policy. Passengers questioned chose an incumbent carrier in order to benefit from the wide range of services available and the high reliability associated with this type of airline. Service reliability was one of the top reasons for choosing an incumbent airline. 20.5\% of Aer Lingus passengers and $18.7 \%$ of

\footnotetext{
${ }^{6}$ Statistical test of means, $5 \%$ significance level.

${ }^{7}$ Statistical test of means, $10 \%$ significance level.
} 
Malaysia Airlines passengers questioned selected this as their principle reason for carrier choice.

\section{Figure 8}

Figure 9 below shows that the low cost airlines' passengers questioned had a very different principle reason for carrier selection. The majority replied that fare was by far the most important factor in choosing to fly on a low cost airline, with flight schedules coming a distant second. Turner (2003) also showed that passengers travelling on a low cost carrier selected fare as their principle reason for carrier choice, while passengers travelling on an incumbent carrier indicated flight timings. Ryanair has given away $20 \%$ of its flights for free in 2003, leading passengers to expect very cheap tickets from the carrier. 5.2\% of Air Asia's passengers identified the ability to book via the Internet as their most important reason for choice of carrier, with a further $4.3 \%$ citing the holiday package offered by the airline on their website.

\section{Figure 9}

The evidence presented in Figures 8 and 9 clearly confirms the principle differences in passengers' perceptions between incumbent and low cost airlines. Passengers are selecting low cost carriers primarily because of their low fares, while passengers selecting full service airlines opt for them in part because of the additional product services they provide.

\subsection{Concluding comments}

Low cost carriers have reshaped the traditional airline business model and have significantly changed the competitive dynamics of the industry. Their highly successful model strictly adheres to the containment of operating costs. Network carriers have gone virtually unchanged throughout the decades relying on hub and spoke systems, serving high to low yield customers and leveraging loyalty programmes, but they are burdened by high costs, complexities and inefficiencies. The incumbents are no longer the leaders of the airline industry in short haul markets.

Two contrasting markets have been examined in this paper; the first, a mature Europe, where liberal skies have allowed low cost carriers to establish traffic hubs across international boundaries, and the second, an Asian economy, where strict bilaterals act to constrain such network developments.

The survey has revealed that while there are differences between passengers travelling on a low cost carrier and those on a full service airline, there appears to be no difference in the attitude and perception of passengers from two very different continents. It would seem that the success of Air Asia in Malaysia, which was based on the Ryanair model 
and which in turn was modelled on Southwest in the US, can be successfully replicated in any part of the world as passengers' opinions and expectations appear consistent.

There is a strong bias towards young people taking low cost carriers and it will be interesting to observe if these travellers migrate towards incumbents when they have more disposable income in the future. It is clear that passengers travelling on low cost carriers place great importance on price and appear to arrange their itineraries using the least expensive airfares. 65\% of those passengers travelling on a low cost carrier surveyed did not look at any other carrier when booking their travel. It would appear therefore that the brand reputation of low fare airlines has become embedded into the minds of consumers.

In contrast, passengers using full service airlines are concerned about price but will tolerate a higher fare in order to gain an advantage through the additional airline products offered by full service carriers. Historically, incumbents have been incapable of matching the fares of no-frills airlines because they were burdened with inefficient operating practices. Low cost carriers are now dominating the leisure markets and are encroaching on business segments. There is significant business traffic for Ryanair especially from the self-employed and employees of small-medium sized enterprises, however large corporations still favour the incumbents, strongly indicating that corporate deals appear to work.

Travellers are willing to connect through secondary airports and to accept no frills in exchange for low fares. Incumbents are retaining their complex and wide range of airline products as a counteractive strategy for higher fares. However, this research clearly indicates that this works only for a specific number of travellers. The way forward for incumbents is to reinvent themselves by adopting those elements of the low cost model that are pertinent to their requirements. The data ascertained from the survey provides evidence that if incumbents could reduce their fares by $30 \%$, it would stimulate a significant number of passengers (over $40 \%$ ) to switch from low cost carriers. It is clear that cross-price elasticities are far from constant, with small percentage changes in fare producing little effect while price changes above $20 \%$ result in large shifts in demand.

It is apparent that passengers travelling on incumbents place strong emphasis on reliability, quality, flight schedules, connections, frequent flyer programmes and comfort, while travellers taking low cost carriers focus almost exclusively on fare. The surveys overall indicate that the ideal for passengers however, would be to have a combination of low fares (at no-frills airline levels) and some of the full service products offered by the incumbent airlines. It would seem therefore that passengers would like to see the two airline models become ever closer! 


\section{References}

Air Transport Intelligence (ATI), 2004. Air Asia to issue RPF for up to 80 new aircraft, Air Transport Intelligence news, $11^{\text {th }}$ June.

Air Transport Intelligence (ATI), 2003. Ryanair plans to lease ‘significant minority’ of fleet, Air Transport Intelligence news, $3^{\text {rd }}$ November.

Aviation Strategy, 2003. Asia’s emerging low cost carriers, Aviation Strategy, May, 2-5.

Aviation Strategy, 2003. Continental barriers to LCC expansion, Aviation Strategy, January, 2.

Barrett, S., 1999. Peripheral market entry, product differentiation, supplier rents and sustainability in the deregulated European aviation market - a case study, Journal of Air Transport Management 5(1), 21-30.

Doganis, R., 2001. The Airline Business in the $21^{\text {st }}$ Century, Routledge, London.

Gilbert, D., Child, D., \& Bennett, M., 2001. A qualitative study of the current practices of 'no-frills' airlines operating in the UK, Journal of Vacation Marketing 7, No. 4, 302-315.

Gillan, D. \& Lall, A., 2002. The economics of the Internet, the new economy and opportunities for airports, Journal of Air Transport Management 8, 49-62.

Ionides, N., 2004. Man of the Moment, Airline Business, April, 27-29.

Ionides, N., 2001. Asian e-volution, Airline Business, March, 74-75.

Lawton, T., 2002. Cleared for Take-Off - Structure and Strategy in the Low Fare Airline Business, Ashgate.

Mason, K., 2001. Marketing low-cost airline services to business travelers, Journal of Air Transport Management 7(2), 103-109.

Mintel, 2000. Visiting Friends and relatives - UK, December.

Mintel, 2002. Short breaks abroad, June.

O’Connell, J. F., Ionides, N., 2004. Room for all?, Airline Business, April, 30-32.

O’Toole, K. \& Pilling, M., 2003. Marketing Mix, Airline Business, December, 70-73.

Paci, E., 1994. Market segments: The major international VFR markets’ EIU travel and tourism analyst 6, 36-50.

Proussaloglou, K., Koppleman, F., 1995. Air carrier demand: analysis of market share determinants, Transportation 22, 371-388.

Ryanair, 2004. www.ryanair.com

Ryanair, 2002. Annual Report and Financial Statement

Sreenivasan, V., 2003. 'Low-Fare dogfight looms, The Business Times, Singapore, December 11.

Still, S., 2002. Fortress Defense, Airline Business, September.

Taneja, N. K., 2003. Airline Survival Kit, Ashgate, Aldershot, 37.

Thomas, G., 2003. In tune with low fares in Malaysia, Air Transport World, May, 45-46.

Turner, S., 2003. Comparison of passenger profiles and selection criteria: a study of London - Amsterdam passengers, ATRS Conference, Toulouse.

Williams, G., 2001. Will Europe’s charter carriers be replaced by “no-frills” scheduled Airlines?, Journal of Air Transport Management 7(5), 277-286. 